Research, part of a Special Feature on Effects of Roads and Traffic on Wildlife Populations and Landscape Function

\title{
Piloting a Non-Invasive Genetic Sampling Method for Evaluating Population-Level Benefits of Wildlife Crossing Structures
}

\author{
$\underline{\text { Anthony P. Clevenger }}^{1}$ and Michael A. Sawaya ${ }^{2}$
}

\begin{abstract}
Intuitively, wildlife crossing structures should enhance the viability of wildlife populations. Previous research has demonstrated that a broad range of species will use crossing structures, however, questions remain as to whether these measures actually provide benefits to populations. To assess this, studies will need to determine the number of individuals using crossings, their sex, and their genetic relationships. Obtaining empirical data demonstrating population-level benefits for some species can be problematic and challenging at best. Molecular techniques now make it possible to identify species, individuals, their sex, and their genetic relatedness from hair samples collected through non-invasive genetic sampling (NGS). We describe efforts to pilot a method to assess potential population-level benefits of wildlife crossing structures. We tested the feasibility of a prototype NGS system designed to sample hair from black bears (Ursus americanus) and grizzly bears (U. arctos) at two wildlife underpasses. The piloted hair-sampling method did not deter animal use of the trial underpasses and was effective at sampling hair from more than $90 \%$ of the bear crossing events at the underpasses. Hair samples were also obtained from non-target carnivore species, including three out of five $(60 \%)$ cougar (Puma concolor) crossing events. Individual identification analysis revealed that three female and two male grizzly bears used one wildlife underpass, whereas two female and three male black bears were identified as using the other underpass. Of the 36 hair samples from bears analyzed, five failed, resulting in an $87 \%$ extraction success rate, and six more were only identified to species. Overall, $70 \%$ of the hair samples from bears collected in the field had sufficient DNA for extraction purposes. Preliminary data from our NGS suggest the technique can be a reliable method to assess the population-level benefits of Banff wildlife crossings. Furthermore, NGS can be an important tool for the conservation value of wildlife crossings for other taxa, and we urge others to carry out evaluations of this emerging methodology.
\end{abstract}

Key Words: Banff National Park; DNA; genetics; non-invasive; road ecology; Ursus americanus; Ursus arctos; wildlife crossing structure

\section{INTRODUCTION}

Compared with other agents of habitat fragmentation, roads cause changes to wildlife habitat that are often more extreme and permanent (Forman and Alexander 1998, Spellerberg 2002, Davenport and Davenport 2006). Roads and road networks not only cause conspicuous changes to physical landscapes, but also alter the patterns of wildlife and the general function of ecosystems within these landscapes (Swanson et al. 1988, Transportation Research Board 1997, National Research Council 2005). Roads may act as barriers to movement and migration, potentially isolating habitats and populations (McRae et al. 2005, Strasburg 2006). Reduced landscape connectivity due to roads could also result in lower survival and reproduction and ultimately smaller populations and decreased population viability (Vos and Chardon 1998, Mumme et al. 2000, Riley et al. 2006).

Over the last decade, land management and transportation agencies have become increasingly aware of the effects of roads on wildlife. Transportation impacts on wildlife populations and 
remedial measures to counter these effects are an emerging science (Evink 2002). Wildlife crossing structures are increasingly used by transportation agencies to meet the need to allow animals to cross roads with reduced hazard to both motorists and wildlife (Goosem et al. 2001, Mata et al. 2005, Gagnon et al. 2007). Like landscape corridors, crossing structures are gaining attention for their role in helping to adapt to changes in species' ranges and distributions resulting from climate change (Vos et al. 2008, Heller and Zavaleta 2009). Intuitively, these measures should enhance the viability of wildlife populations. Studies have demonstrated that a broad range of species will use wildlife crossing structures (Ng et al. 2004, Dodd et al. 2004), which can reduce barrier effects and road-related mortality for some species (Clevenger et al. 2003, Dodd et al. 2007b, Huijser et al. 2007).

Until now, research has largely focused on the amount of use crossings receive from a range of wildlife species, e.g., the greater the use, the more successful the crossing structure. Questions remain as to whether these structural measures actually improve population viability and which species might benefit from them (van der Ree et al. 2009). Previous studies have yet to go beyond showing that organisms will use crossing structures. But use does not necessarily equate to gene exchange and improved demographic and ecological processes that characterize functional connectivity (Crooks and Sanjayan 2006, Kindlmann and Burel 2008, Kadoya 2009). Research that addresses these unanswered questions will require new methods that allow assessment of connectivity for populations, communities, and ecological processes.

Obtaining empirical data to demonstrate the population benefits of wildlife crossing structures for some species can be problematic. Wide-ranging, fragmentation-sensitive species such as bears (Ursus sp.), cougars (Puma concolor), and wolverines (Gulo gulo) typically are elusive and occur in relatively low densities (Weaver et al. 1996, Linnell et al. 2001, Flagstad et al. 2004). At present, the most reliable method involves live trapping, marking, and closely monitoring the fine-scale movements of individuals within a population, but for logistical reasons, this is often impractical (Nathan et al. 2003). Demonstrating that crossings provide population-level benefits (adult male and female movement across roads; juvenile dispersal, survival and reproduction of offspring) using radiotelemetry would require a decade or more of intensively tracking movements of many marked individuals. This is an inordinately long time for management to wait for answers from research.

Molecular techniques enable the identification of species, individuals, their sex, and genetic relatedness from hair samples collected through non-invasive genetic sampling (NGS) methods (Foran et al. 1997, Reed et al. 1997, Sloane et al. 2000, Frantz et al. 2004, Durnin et al. 2007). Noninvasive genetic sampling has been emerging over recent years as an important tool for detecting the dispersal of individuals, assessing population viability, and ultimately restoring local and regional connectivity (Epps et al. 2005, Cushman et al. 2006, Huck et al. 2008, Nathan et al. 2008). Compared with radiotelemetry methods, NGS could potentially be a relatively cost-effective means of acquiring critical information-in a relatively short period of time - regarding the amount and level of genetic interchange facilitated by crossing structures, without ever having to capture or see the animal.

The development of a NGS method that provides detailed information on the demographic and genetic consequences of animal movement at crossing structures could be a valuable tool for enhancing our scientific understanding of the population-level benefits of these measures. This would require detailed information on the genetics of a focal population affected by transportation infrastructure in addition to the genetics of individuals moving through wildlife crossing structures to maintain connectivity within the affected population.

We describe a NGS method designed to obtain genomic DNA (extracted from hair samples) to be used in evaluating the population-level benefits of wildlife crossing structures. First, we illustrate the need to scale up from single or multi-species monitoring to a population-level approach to evaluate mitigation measure performance. We focus on black bear (Ursus americanus) and grizzly bear ( $U$. arctos) populations impacted by a major transportation corridor in the Banff-Bow Valley (Gibeau et al. 2002, Hebblewhite et al. 2003, Chruszcz et al. 2003). We describe a pilot study testing the efficacy of a NGS method of collecting hair samples from bears using wildlife crossing structures. Finally, we discuss the added value of 
non-invasively collected genetic data for conservation and management of wildlife populations.

\section{STUDY AREA}

Our study area was situated in the Bow River Valley along the Trans-Canada Highway (TCH) corridor in Banff National Park, Alberta, Canada (Fig. 1). Banff is the most heavily visited national park in Canada, with over 4 million visitors each year. Most visitors arrive by private vehicle or motor coach along the TCH. The highway is a major commercial motorway between Calgary and Vancouver. Annual average daily traffic volume at the park's east entrance was over 17,000 vehicles daily in 2007 and is increasing at a rate of $2.5 \%$ per year (Parks Canada Agency, unpublished data).

Transportation and human infrastructure have resulted in significant habitat loss and fragmentation in the Bow Valley. The town of Banff, access roads to Banff town site, the Canadian Pacific Railway mainline, a primary two-lane highway (Highway 93), and a secondary road that parallels the TCH are all considered landscape stressors that threaten ecological integrity and regional biodiversity (Banff-Bow Valley Study 1996). Between 1980 and 1998, the first $45 \mathrm{~km}$ of the TCH from the eastern park boundary (Phases 1, 2, 3A) were widened to four lanes (McGuire and Morrall 2000). During this time, a total of 23 wildlife crossing structures (21 underpasses and two overpasses) were constructed sequentially, along with $2.4 \mathrm{~m}$ high fencing to reduce wildlife-vehicle collisions and facilitate wildlife movement across the four-lane section of the TCH (see Clevenger et al. 2009). The spatial distribution, design, and specific dimensions of the crossing structures are found in Clevenger and Waltho $(2000,2005)$.

\section{MONITORING MULTI-SPECIES USE OF WILDLIFE CROSSING STRUCTURES}

All 23 crossing structures in Phases 1, 2, and 3A have been continuously monitored for wildlife passage since 1996 using track pads (Clevenger et al. 2009). Track pads were established at each end of every wildlife underpass perpendicular to the direction of animal movement (Bider 1968). Track pads spanned the width of each underpass and were ca. $2 \mathrm{~m}$ long. Track pads on wildlife overpasses consisted of a single track pad located at the center, spanning the width, and approximately $4 \mathrm{~m}$ long. We visited each crossing structure at 3- to 4-d intervals year round. We detected species' use of the crossing structure by their tracks, estimated the number of individuals, their direction of travel, and whether they traversed the crossing structure. Although we were able to estimate the number of individuals at a given crossing visit by their tracks, we were unable to determine the number of unique individuals (or sex and age) from one crossing visit to another. Because of difficulties in consistently identifying tracks of small- and medium-sized mammals, we limited data collection to mammals the size of coyotes (Canis latrans) and larger (see Clevenger and Waltho 2000).

Infrared motion-triggered cameras (Reconyx $\mathrm{x}^{\mathrm{TM}}$, Holmen, Wisconsin, USA) were used at some wildlife crossing structures in addition to track-pad monitoring (Ford et al. 2009). Photos were downloaded onto a handheld computer (HewlettPackard $^{\mathrm{TM}}$ iPAQ hx2490b, Palo Alto, California, USA) each time the crossing structures and track pads were visited. Photos were classified using a customized database form to record the species, number of individuals, and direction of travel.

To date, more than 180,000 crossings by 11 large mammal species have been recorded since November 1996(Clevenger et al.2009). Monitoring data were used in two separate analyses to identify attributes that facilitate wildlife use of crossing structures that vary in age. The first analysis demonstrated that human activity consistently ranked as the most important factor affecting species use at 10-year-old Phases 1 and 2 wildlife underpasses ( $n=12$; Clevenger and Waltho 2000). A subsequent and similarly designed analysis using 3 years of post-construction monitoring data from the newly constructed Phase 3A wildlife crossing structures $(n=12)$ indicated that structural attributes had greatest explanatory power, whereas landscape and human-related factors were of secondary importance (Clevenger and Waltho 2005).

Because the two detection methods used in the analyses only allowed for species identification based on tracks or photographs (to genus for deer [Odocoileus sp.]), we were unable to determine the number of different individuals using the crossings, their sex, or genetic relatedness. High rates of movement at wildlife crossing structures may not necessarily correlate with the functional connectivity 
Fig. 1. Location of 23 engineered wildlife crossing structures along the Trans-Canada Highway in Banff National Park, Alberta, Canada. Cascade, Buffalo, and Edith were excluded from hair sampling. Nonengineered underpasses are 5-Mile Bridge and 40-Mile Creek (Map prepared by B. Dorsey).

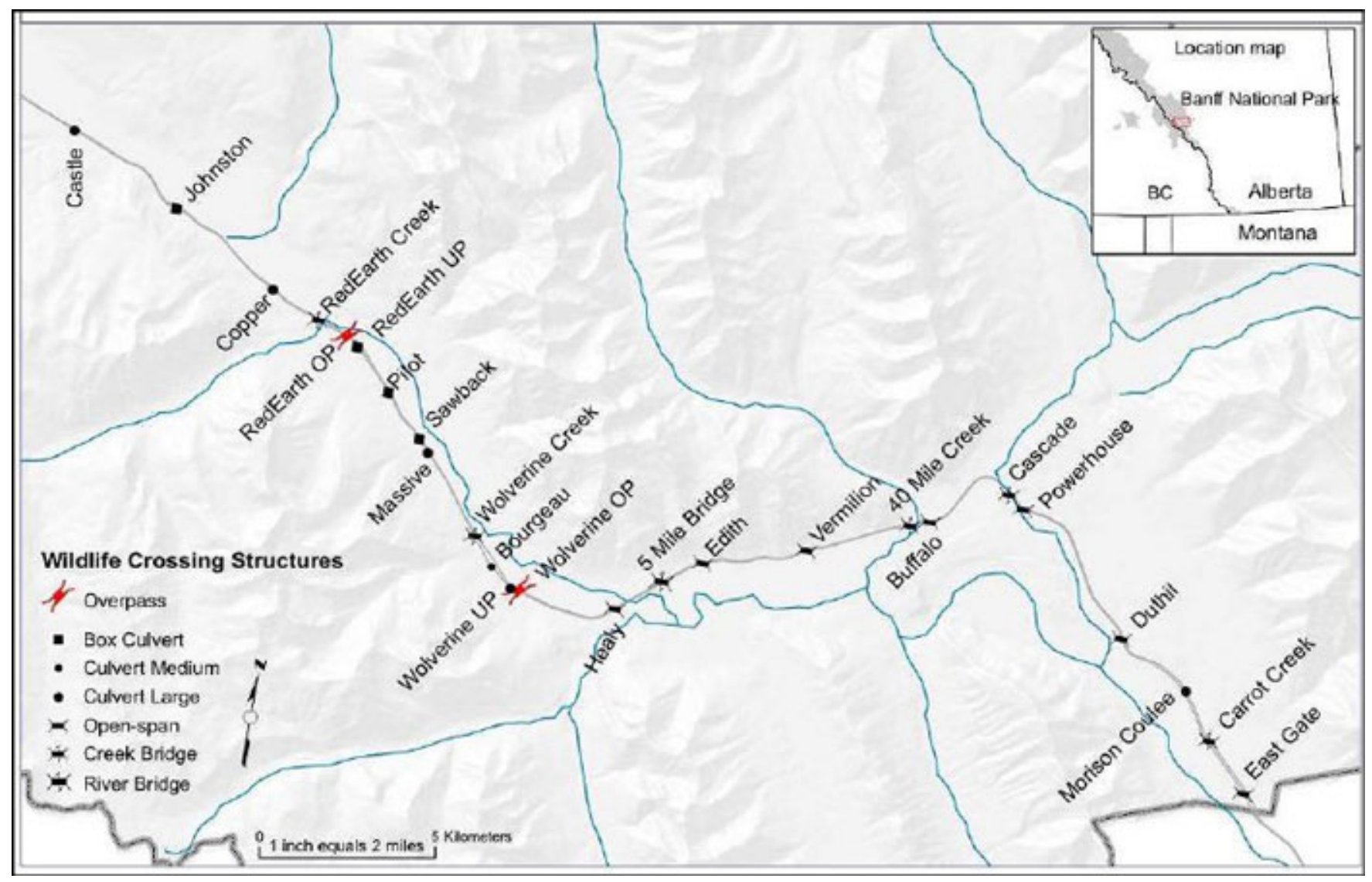

of a landscape (Strasburg 2006). Discrepancies between dispersal and gene flow were found across a major multi-lane freeway in southern California (Riley et al. 2006) and may be more widespread than expected. Furthermore, a recent review paper reported there have been few empirical results that demonstrate highway wildlife overpasses are effective at preventing genetic isolation (Corlatti et al. 2009). Therefore, wildlife crossing structures should be evaluated for how well they move organisms, link habitats, and ensure genetic connectivity among populations. New tools and methods that measure connectivity and corridor efficacy would aid data collection and greatly benefit transportation and land managers seeking to design effective wildlife crossing mitigation.

\section{FEASIBILITY OF MONITORING WILDLIFE CROSSING STRUCTURES USING NON-INVASIVE GENETIC SAMPLING}

Connectivity can be achieved in several ways that translate to varying levels of population viability (Carroll 2006, Kadoya 2009). Techniques using molecular genetics or stable isotopes are rapidly evolving and offer particular promise to reveal landscape connectivity for populations (Webster et al. 2002, Nathan et al. 2003, Hobson 2005, Damschen et al. 2006). Genetic approaches have successfully measured gene flow for small organisms (Aars and Ims 1999, Coffman et al. 2001, Keyghobadi et al. 2005), but quantifying movements and connectivity of large, wide-ranging 
mammals employing genetic techniques can present real challenges.

Over the past decade, significant advances have been made in the development of NGS techniques of hair collection coupled with genetic analyses to obtain DNA signatures from individuals within populations over extensive areas (Foran et al. 1997, Flagstad et al. 2004, Kendall et al. 2008). This sampling approach has proven particularly effective for wide-ranging terrestrial carnivores (Woods et al. 1999, Mowat and Strobeck 2000, Schwartz et al. 2003) and has been used to estimate grizzly bear population size (Boulanger et al. 2002), model population density and distribution (Apps et al. 2004, Kendall et al. 2008), and characterize population connectivity (Proctor et al. 2005, Kendall et al. 2009). Thus, NGS of genomic DNA from hair is a proven and reliable technique for longterm monitoring of bear population trends through time and space.

Few researchers have evaluated the functionality of regional landscape corridors for mammals. Dixon et al. (2006) used NGS, microsatellite analysis, and population assignment tests to evaluate the effectiveness of a regional corridor in connecting two Florida black bear ( $U$. a. floridanus) populations. Mansergh and Scotts (1989) showed that use of an under-road tunnel restored population structure of mountain pygmy-possums (Burramys parvus). van der Ree et al. (2009), however, found that the underpass reduced, but did not completely remove the road impact on population size. We are unaware of any research assessing the efficacy of a suite of wildlife crossing structures in maintaining or restoring demographic and genetic connectivity of mammal populations.

\section{Objectives}

Being able to identify individuals and their sex, and the relationships of animals using wildlife crossing structures would be a first step toward measuring the population-level effects of a highway mitigation complex, like that in Banff National Park, Alberta. We conducted a pilot study to test the efficacy of a NGS system to obtain hairs of large mammals using wildlife crossing structures. Our non-invasive technique targeted grizzly and black bears because of their regular use of the Banff crossing structures (Woods et al. 1999, Clevenger et al. 2002), their conservation status as indicator species, and the existence of well-tested NGS methods used to monitor bear populations. First, we wanted to determine how bears would respond to wildlife underpasses with a hair-sampling system in place. We quantified the number of times bears approached the underpasses and categorized their behavior as avoidance (turned around) or nonavoidance (passed through). Secondly, of the individuals that passed through the crossing structure, we measured how successful the system was at obtaining hair samples from bears. Videomonitoring of failed attempts to obtain hair samples would provide clues as to possible reasons why animals did not leave hair behind. This information then was used to adjust or modify the hair-sampling system to improve hair-sampling success.

Our study was conducted during two summers. The first year (2004) consisted of evaluating various designs of hair-sampling systems to obtain hair samples from bears at two wildlife underpasses (research and development). The second year (2005), we tested the one method that proved the most promising at meeting our study objectives (method testing).

\section{RESEARCH AND DEVELOPMENT OF A NON-INVASIVE GENETIC SAMPLING METHOD}

\section{Methods}

\section{Hair sampling}

In summer 2004, we evaluated different hairsampling methods at two open-span wildlife underpasses on the TCH in Banff National Park, Alberta. The wildlife underpasses were identical in design and dimensions, were $18 \mathrm{~km}$ apart, and constructed over 20 years ago (Rettie et al. 2009). The two underpasses were selected because previous monitoring indicated high use by large carnivores and low visitation by humans. Our concept of hair sampling at wildlife crossing structures was to be a passive hair-collection method, but with similar design as the commonly used barbed-wire "corral"-type hair snare used in field studies designed to estimate bear population size (Long et al. 2008). Hair corrals are formed with a perimeter of barbed wire, $45-50 \mathrm{~cm}$ high, wrapped around several trees and encircling a central bait or lure (Woods et al. 1999, Kendall and McKelvey 2008). We tried and evaluated several hair-sampling methods based on the barbed-wire design. 
We installed the first hair-capturing device in stages to allow time for wildlife to adapt to placement of barbed wire across the wildlife underpass (Fig. 2). We used barbed wire consisting of 15.5 gauge wire with barbs spaced approximately $15 \mathrm{~cm}$ apart. The steel support posts were put in place first. Guy wires were used to stabilize the posts. We then installed woven-wire fencing behind the steel posts and extended to the interior underpass walls to ensure that the animals would not go around the barbed wire as they passed through. The final step involved stringing barbed wire across the central portion of the wildlife underpass and securing it to the steel posts. The staged installation process occurred over a $10-d$ period.

Two video cameras were used to record the 24-h behavior of animals as they approached the hairsampling system from either direction. At a distance of 20-25 $\mathrm{m}$ from the barbed wire, we placed infrared sensors that activated the video cameras when animals moved toward the underpass and broke the infrared beam. During nighttime hours, the system was configured to turn on infrared lights to illuminate the underpass. Video cameras and infrared motion-activated sensors were operated with 12-volt deep cell batteries. We continued to monitor track pads at the two underpasses (as described earlier) while visiting the wildlife underpass for hair samples. Hair obtained from bears that passed through the two underpasses was collected daily and stored in paper envelopes. A complete passage through an underpass by a bear was classified as a crossing event; however, from one crossing event, multiple hair samples could be obtained. No baits or scent lures were used to attract animals to the wildlife underpasses.

\section{Genetic analysis}

Samples were analyzed at Wildlife Genetics International (Nelson, British Columbia, Canada), a lab that specializes in non-invasive genetic samples. DNA extraction and microsatelite analysis followed protocols for non-invasive genetic samples first described in Woods et al. (1999) and later detailed in Paetkau (2003). DNA extraction from hair samples was performed using QIAGEN's DNeasy® Tissue kits. Ten guard-hair roots were used for each DNA extraction, when available. When samples of underfur were analyzed, the entire sample of underfur was used for extraction rather than clipping individual roots. Species tests consisted of a sequence-based analysis of $16 \mathrm{~S}$
rRNA, mtDNA gene (Johnson and O'Brien 1997). Samples were compared with reference data from lynx (Lynx canadensis), cougar, bobcat (L. rufus), house cat (Felis catus), dog (C. lupus familiaris)/ wolf ( $C$. lupus), black bear, grizzly bear, coyote, deer, moose (Alces alces), elk (Cervus elaphus), and snowshoe hare (Lepus americanus). Species identifications were assigned whenever an exact match was observed between a reference sample and the result.

The use of an insufficient number of variable markers can lead to erroneous individual identifications because different individuals can end up having identical genotypes. This can be avoided by careful marker selection at the beginning of analysis. Four different sets of microsatellite markers were used for the analysis of individual identity. Background genetic data were used from black and grizzly bears in Banff National Park. A set of six to ten markers known to be sufficiently variable to produce reliable assignments of individual identity in both species was used.

Multi-locus microsatellite analysis was performed in three phases following Paetkau (2003). First, an initial pass was made with all six to ten microsatellite markers. Samples that produced solid data for fewer than half of the markers were excluded from further consideration. This approach was developed by the lab based on experience that showed that such samples tend to be error prone, and DNA runs out before they are able to produce complete and accurate genotypes for the samples. Eliminating marginal samples at an early stage improves the efficiency of the analysis without changing the final result.

The next round of analysis involved samples that produced incomplete results during the first phase, but were not excluded, and made use of $5 \mu \mathrm{L}$ of DNA per reaction instead of $3 \mu \mathrm{L}$ used during the first pass. Most samples had complete genotypes after this phase, but samples that were sufficiently weak in both rounds were considered "failed" samples.

The third round of analysis involved error checking the multi-locus genotypes by scrutinizing pairs of samples that mismatched at one or two loci. This process identifies allelic dropout, false alleles, and scoring errors (Paetkau 2003). Samples from different individuals should differ by more than two loci according to their mismatch probabilities 
Fig. 2. Illustration of hair-sampling system at wildlife underpass in Banff National Park (Illustration by S. Harrison).

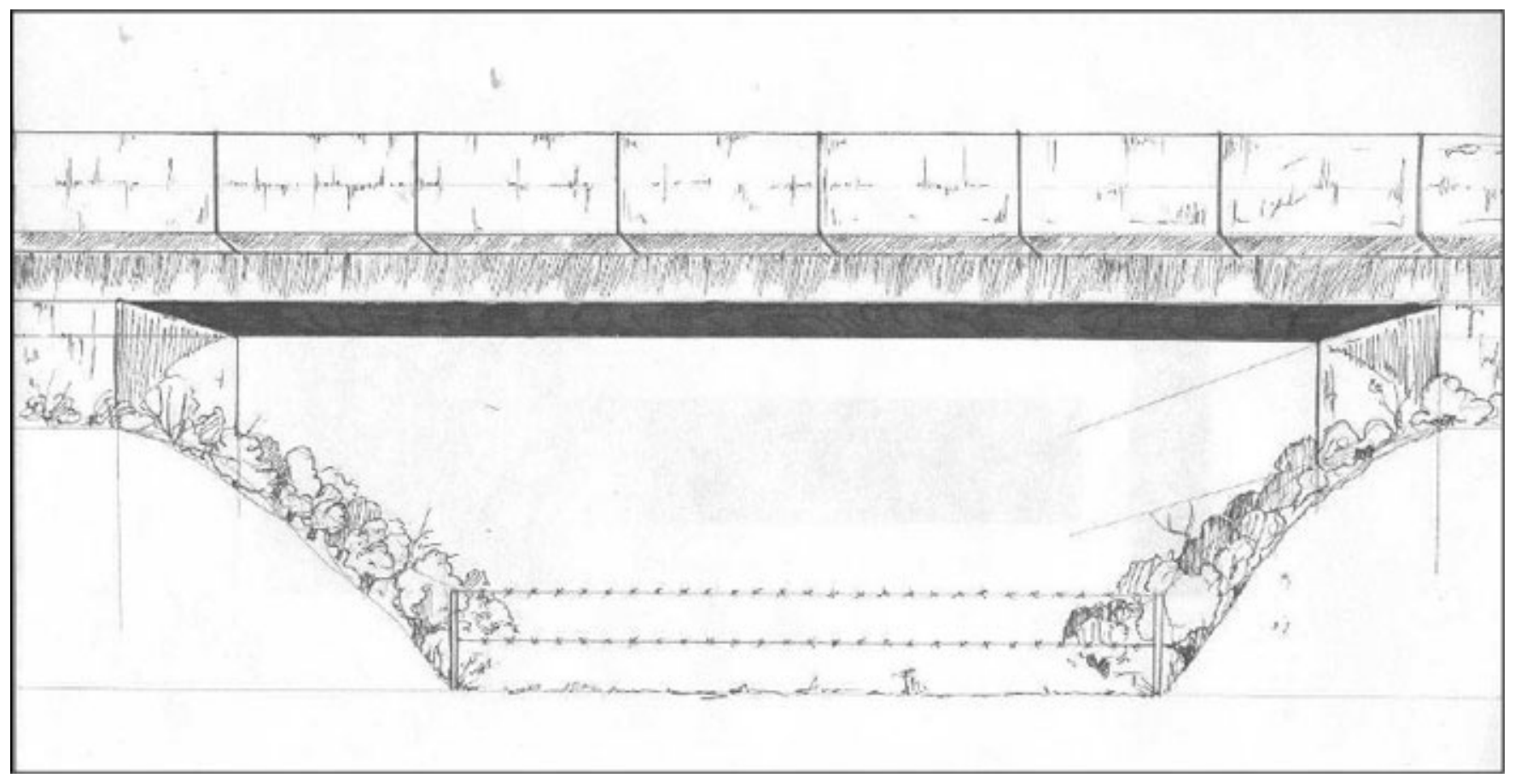

(Kalinowski et al. 2006) so samples with one or two mismatches were double checked and reanalyzed if necessary. Once the genotypes were checked for errors and the multi-locus genotypes were completed, a computer search for identical genotypes was performed and individuals were defined for each unique multi-locus genotype.

\section{Results}

The 2004 tests revealed how animals responded to the hair-sampling system and allowed us to adaptively modify the system based on their behavior. Species responded differently to each design as each had varying degrees of success. We briefly summarize below how well each of three methods performed before describing the prototype method tested the following year.

The first design consisted of one strand of barbed wire secured to steel posts suspended $0.5 \mathrm{~m}$ above the ground spanning the width of the underpass. As mentioned above, a variation of this method is used to estimate bear population size (Woods et al. 1999, Kendall et al. 2008). We quickly discovered that this design was ineffective at obtaining hair from bears using the underpasses. Although bears often were able to jump over or go under the single wire, video images showed that no hair was snagged when bears came into contact with the wire, thus suggesting that contact with the wire must be forceful enough for hair to be snagged on a barb.

Glue boards and other highly adhesive materials have been successfully used to snag hair from mammals non invasively (Sloane et al. 2000, Mowat and Paetkau 2002, Frantz et al. 2004, Long et al. 2008). Therefore, the second design consisted of the same $0.5 \mathrm{~m}$ high, single-strand, barbed wire but intertwined with a highly adhesive string (The Landing Strip, Can-Vet Animal Health Supplies, Cambridge, Ontario, Canada) to improve hair capture and retention. Video monitoring showed in short time that this design proved ineffective at snagging hair as bears were repeatedly able to avoid 
the barbed wire and adhesive by jumping over or going under the wire.

The third and final hair-sampling design consisted of two strands of barbed wire with intertwined adhesive string at $35 \mathrm{~cm}$ and $75 \mathrm{~cm}$ heights at both underpasses. Previous single strand designs were ineffective at snagging hair from bears. We believed that by placing one strand high (higher than bears are likely to jump over) and one strand low (too low for bears to go under without significant rubbing), with $40-50 \mathrm{~cm}$ between strands, would not be intimidating for bears, but would prove difficult for them to pass through without eventually rubbing against one of the strands. Two strands also have twice as many barbs to potentially collect hair as bears would have a greater probability of passing through the center. The day after installing this twostrand design, a black bear ran through one of the underpasses, jumped between the strands and in doing so multiple hairs were snagged on the top strand.

The two-strand system was tested from 10 August to 7 October 2004. With the two-strand design in place, the hair-sampling success rate was $54 \%$ (hair samples were obtained in seven of 13 crossing events) for black bears. One grizzly bear used one of the underpasses after August and did not leave hair. The low use by grizzly bears at the two wildlife underpasses during this period is largely due to them moving out of the valley and up to higher elevations after early July (Hamer and Herrero 1987, Gibeau 2000).

During 2004 trials, we collected a total of 97 DNA samples from the two wildlife crossing structures. Nine samples were collected from black bear crossing events and four from grizzly bear crossings. Among non-target species, 57 samples were collected from elk, 18 from deer, eight from moose, and one from coyote.

The amount of material that was available for extraction was generally quite high, with 30 samples containing more than two guard-hair roots, a level at which the lab expected to see high success rates. A total of 13 of the 30 samples failed, either during species analysis or during individual identification. Possible explanations for this high failure rate was suggested to be due to degradation during extended periods in the field, inhibition by compounds in the adhesive (glue), or inadequate adhesive strength such that shed hairs were collected on the wire/ adhesive, whereas other embedded hairs were not snagged. Extraction success rates are much higher from snagged or plucked hairs compared with shed hairs (D. Paetkau, Wildlife Genetics International, personal communication).

When bears were videoed crossing the underpass, the rate of successful hair capture for the two-strand method was greater than $50 \%$, despite the relatively few bear crossing events, and thus warranted further examination. Given the lower than expected extraction success rates, possibly due to the adhesive, we opted to go without it and use only the two strands of barbed wire in the prototype hairsampling method the following summer.

\section{TESTING OF A NON-INVASIVE GENETIC SAMPLING METHOD}

\section{Methods}

In 2005, we wanted to determine how the method performed for an entire season, thus we tested the efficacy of the prototype hair-sampling method for both bear species using the same two underpasses (Fig. 2). We evaluated the method using the following metrics: (1) quantifying the number of approaches, (2) quantifying the behavior of individuals entering the underpass (avoidance/ turnaround or pass-through), and (3) if they passed through, quantifying the rate of success at obtaining hair samples. Video monitoring of failed hair sampling during crossing events provided information to help make adjustments and improve hair-capture success. We tested the prototype method from May to mid-August 2005. The two underpasses were visited daily with concurrent information collected on animal use of the underpass and hair-sampling success from the track pads, video cameras, and the hair-sampling system. Hair samples obtained from barbs ranged from one single hair to tufts of more than 20 hairs, however, in general, collected samples from a single barb consisted of roughly five to ten hairs.

Hair samples were analyzed with same genetic methods described above for the research and development section. 


\section{Results}

Between 5 May and 13 August 2005, there were a total of 56 approaches to the two underpasses by large carnivores; 43 approaches were made by bear species, 24 black bears and 19 grizzly bears. Bears that approached the underpasses but then turned around or avoided the underpasses occurred less than $10 \%$ of the time; for black bears, two out of 24 times $(8 \%)$, whereas for grizzly bears, one out of 19 times $(5 \%)$. The hair-capture success rate was high for both bear species. During crossing events, hair was obtained from bears $88 \%$ of the time they used the two underpasses. Of 22 crossing events made by black bears, hair samples were obtained $82 \%$ of the time. Hair samples were obtained from grizzly bears during $94 \%$ of the crossing events $(n=18$; Fig. 3).

Although the hair-sampling method was designed for bear species, we were interested in knowing how effective it might be at obtaining hair samples from non-target carnivore species in the study area. Cougars can easily avoid the two strands of barbed wire by jumping over them, however, hair samples were obtained from three out of five $(60 \%)$ crossing events (Fig. 4). A single wolf avoided the underpasses the first four times it approached the underpass, but on each visit, the single wolf successively came closer to the barbed wire. On the fifth and subsequent approaches the wolf crossed through the barbed wire and the underpass. Hair samples were obtained from the same individual during three of five $(60 \%)$ crossing events. Many hair samples from ungulates were regularly found on the barbed wire at each crossing visit. However, we did not collect hair samples from ungulate species using the wildlife underpasses. We were able to identify where certain species and individuals crossed the barbed wire from the location of tracks found on track pads and review of video monitoring.

We sent a total of 50 hair samples for species, individual, and sex identification to the Wildlife Genetics International lab in Nelson, British Columbia. One or more hair samples were obtained from a single crossing event. Thirty-six of the 50 samples were from bears: 20 samples were presumed to be from grizzly bears, 16 from black bears, and 14 were of unknown origin. Grizzly bear and black bear samples were obtained from 12 and 13 crossing events, respectively. Five samples failed to produce enough DNA for extraction (one grizzly bear sample, four black bear samples) and one black bear sample consisted of only one hair shaft with no root.

Species identifications were made from 20 grizzly bear samples (including one from a misidentified "wolf" sample) and 11 black bear samples. Although individual and sex identification were not the objectives of our method testing, the analysis revealed that three female and two male grizzly bears used one wildlife underpass, whereas two female and three male black bears were identified using the other underpass. Of the male grizzly bears, one made one crossing event, and the other crossed twice. Of female grizzly bears identified, one crossed nine times, and the other two only crossed once. An adult female accompanied by three cubs made all female grizzly bear crossings at the Healy underpass. Although hair samples were obtained from the mother nine times, samples were obtained from two of the cubs only during one crossing event. Because of their small size, it is difficult to obtain hair samples from young bears. Of the three male black bears identified by genetic analysis, two made two crossing events, and one crossed once. Of the two female black bears, one crossed twice, and the other crossed six times.

Of the 36 hair samples from bears analyzed, five failed, resulting in an $87 \%$ extraction success rate; six more were only identified to species. Overall, $70 \%$ of the hair samples from bears collected in the field had sufficient DNA for extraction purposes. Genetic analysis of some hair samples of unknown origin resulted in genotyping and identifying individual elk, deer, and moose during the testing period.

\section{DISCUSSION}

Roads can be powerful influences on the demography and genetics of wildlife populations (Riley et al. 2006, Mumme et al. 2000, Marsh et al. 2008). Therefore, it is important to gain a better understanding of whether the conservation measures designed to reduce the adverse effects of roads actually benefit species and their populations rather than just individual organisms. Until now, we are aware of only two studies that have documented the population-level benefits of road mitigation measures such as wildlife crossing structures 
Fig. 3. Grizzly bear passing through hair-sampling system at one of the wildlife overpasses in Banff National Park.

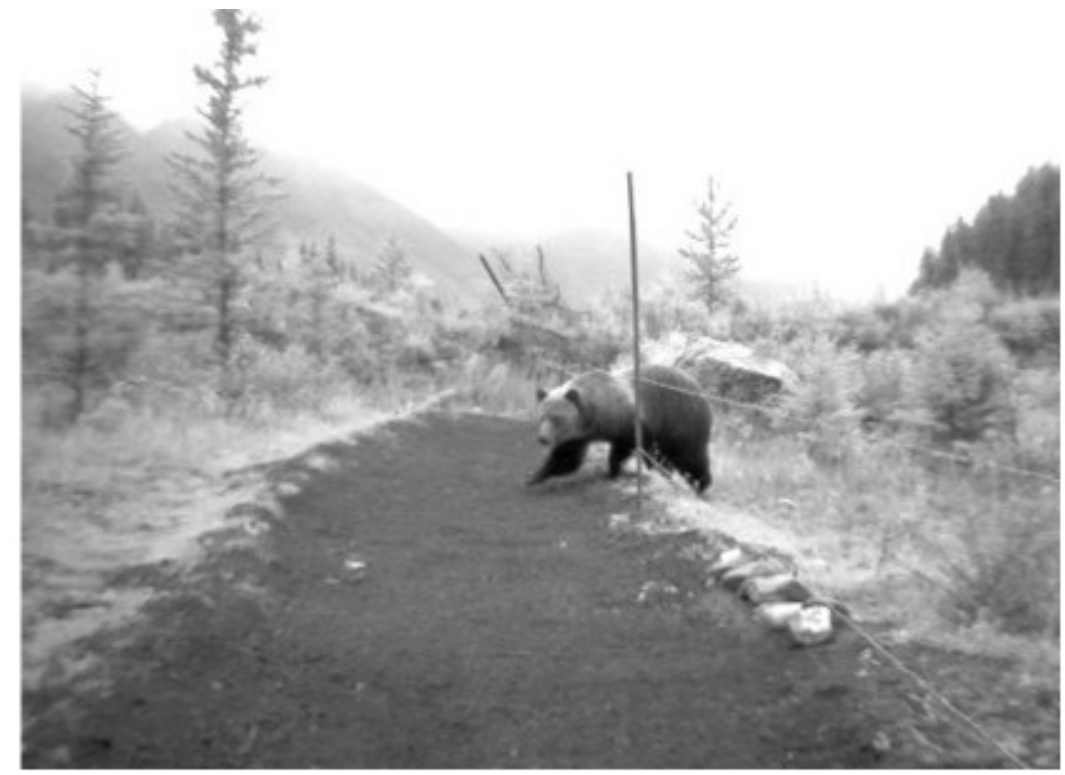

(Mansergh and Scotts 1989, van der Ree et al. 2009). There is a need for additional evidence-based support that wildlife crossing structures contribute to long-term persistence of wildlife populations. Over 12 years of data collected in Banff have shown that many large mammal species such as black and grizzly bears use the wildlife crossing structures each year, but until now the number of individuals and their sex have remained unknown.

\section{Efficacy of Non-Invasive Genetic Sampling at Wildlife Crossing Structures}

Our feasibility study demonstrated that the NGS method designed to collect hair from bears using two wildlife underpasses was effective in meeting the study objectives. The hair-sampling method did not substantially deter bear or other large mammals from using wildlife crossing structures. The piloted hair-sampling method proved to be an effective and non-invasive tool that will enable a better understanding of the conservation benefits of wildlife crossing structures. Besides the low avoidance rate we documented at the trial underpasses, the hair-capture success rate was high for the two bear species.
Not all hair samples provide a source of DNA for extraction (Goossens et al. 1998). DNA extracts from NGS sources can be low in concentration or degraded (Taberlet et al. 1996). These factors can lead to reduced amplification success or unacceptable genotyping error rates (Goossens et al. 1998), making studies unfeasible or biasing results (Waits and Leberg 2000, Creel et al. 2003). The quality of hair samples obtained in our pilot study was relatively high as DNA extraction occurred in more than $70 \%$ of the samples analyzed from the two wildlife underpasses.

Hair-sampling systems could potentially limit animal movements, thus reducing connectivity between populations. Therefore, it is important to be able to monitor how not only target but non-target wildlife respond to the hair-sampling system at wildlife crossing structures. Single wolves were reluctant to pass through the trial underpasses the first four times they approached. However, each time the lone wolf successively came closer to the hair-sampling system and eventually began using the underpass regularly. These observations, in addition to subsequent observations from camera monitoring during an ongoing study (M. Sawaya, personal observation), suggest that initially some 
Fig. 4. Cougar passing through hair-sampling system at one of the wildlife underpasses in Banff National Park.

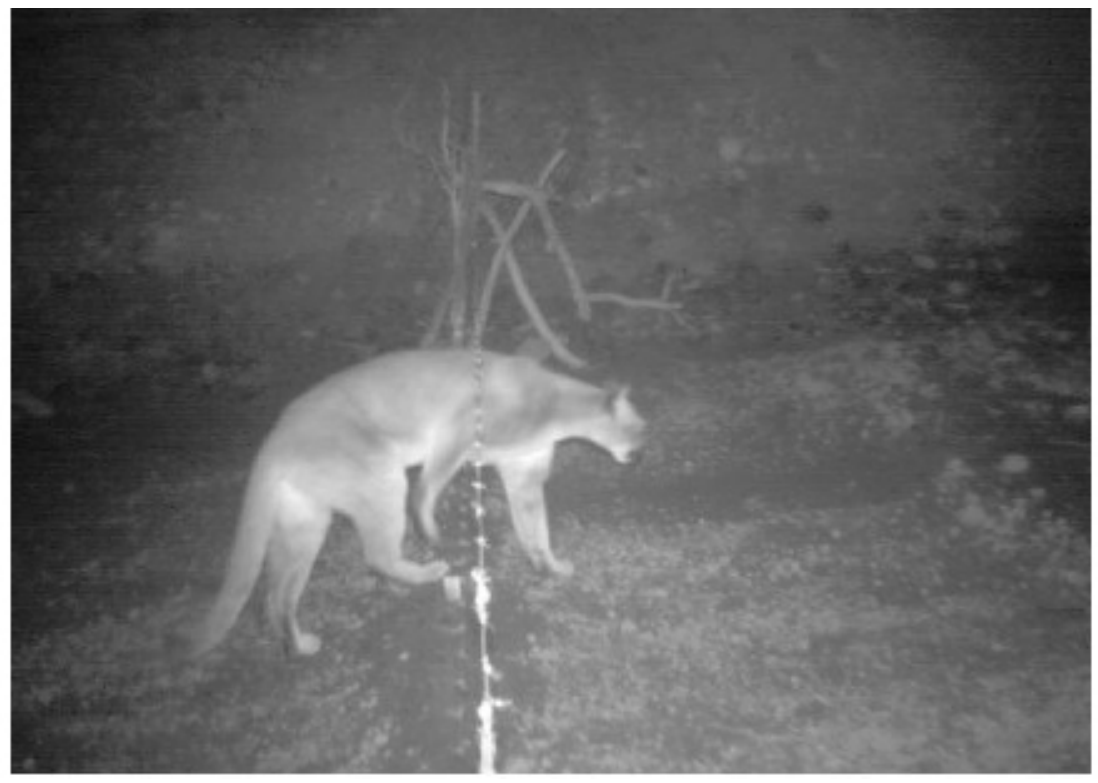

species may be reluctant to use wildlife crossing structures adapted for hair sampling. However, with time, some animals appear to adapt to them and use them regularly.

Although many monitoring efforts and studies report on how frequently different taxa are detected using wildlife crossing structures (Foster and Humphrey 1995, LaPointe et al. 2003, Mata et al. 2005, van Vuurde and van der Grift 2005, Grilo et al. 2008), virtually nothing is known about the sex, age, and reproductive status of the individuals detected. Like landscape corridors, wildlife crossing structures are designed to facilitate movement among all sex and age classes (Beier and Noss 1998, Bennett 1999). However, scientifically understanding how much movement is needed to maintain viable populations is a difficult question to answer (Carroll 2006), especially for such wideranging species as grizzly bear, lynx, and wolves in our study area.

In this study, we documented two different male and three female grizzly bears using one of the trial underpasses during a 31/2-month period. Similarly, three different male and two female black bears were found using the other underpass. These are minimum estimates of the number of males and females using the two crossing structures as some individuals may have used them without leaving hair samples. Bears are not territorial species, however, males tend to have large home ranges that encompass multiple ranges of breeding females (Rogers 1987, Stenhouse et al. 2005). Because males are not territorial, the ranges of adult males may overlap as well (Powell 2000). The preliminary data on the number of individuals and their sex at the trial underpasses are in agreement with the expectations of use according to sex given the social and spatial organization of both bear species. Whether movement at the wildlife crossing structures by males and females results in the establishment of home areas and successful breeding attempts after crossing the highway will be assessed from an ongoing population-level study currently underway (M. Sawaya, unpublished data).

Our pilot study has shown that non-invasive hair sampling can be an effective means of identifying species, individuals, and sex of animals using wildlife crossing structures. The next step in developing this methodology requires detailed 
information on the genetics of a focal species population affected by transportation infrastructure in addition to the abovementioned genetics of individuals moving through wildlife crossing structures to maintain connectivity within the affected population. Non-invasive sampling of genomic DNA from hair has become an established technique for obtaining demographic information from bear populations (Kendall et al. 2009) and will facilitate the collection of background population data. The combined information should enable a rigorous evaluation of how populations are affected by the operation of wildlife crossing structures.

\section{Comparative Benefits of Non-Invasive Sampling at Wildlife Crossing Structures}

Our method was successful in non-invasively collecting hair samples from bears using wildlife crossing structures. There are many advantages and disadvantages to using this NGS approach to evaluate wildlife crossing structures. Track pads, remote cameras, NGS, and radiotelemetry methods all can be used to address research questions related to wildlife crossing structures (Table 1). Track pads were the first method employed to assess the use of wildlife crossing structures (Yanes et al. 1995, Rodriguez et al. 1997). Remote cameras have increased in popularity as they have become more affordable and reliable (Mansergh and Scotts 1989, Dodd et al. 2007a, Kleist et al. 2007, Ford et al. 2009). The recent trend in conservation biology to use NGS for studying wildlife populations has led to the natural transition of using this method to monitor and assess the efficacy of wildlife crossing structures. Although NGS cannot be used to answer all research questions, it can be used to address many relevant questions regarding the ability of wildlife crossing structures to promote connectivity.

One advantage of NGS over traditional methods that have been used to monitor wildlife crossing structures is that NGS can be used to identify individuals and then track those individuals over time. Although track pads and remote cameras can be used to estimate the number of individuals of a given species at one crossing event, they cannot distinguish among individuals at any one crossing event or different events in time. Another advantage NGS has over traditional methods is that genetic data can be used to examine relatedness. Markrecapture studies can also generate this type of data from blood or tissue samples collected during capture, but obtaining this information requires intense capturing efforts over an extensive area, which can be costly and still fall short of sampling a large part of the target population. Regardless of how the genetic data are obtained, microsatellite allele frequencies can be used to estimate relationships and parentage of individuals using the wildlife crossing structures. Allele frequency data can also be used to estimate changes in gene flow if the data were collected in a BACI (Before-AfterControl-Impact) framework (Balkenhol and Waits 2009).

A disadvantage of using NGS sampling to monitor wildlife crossing structures is that it must be used in combination with remote cameras or track pads to be able to determine the direction of travel of individuals using the crossing. A hair sample alone cannot indicate the direction of movement of individuals using crossings. The cost of installing track pads is relatively inexpensive; remote cameras can cost between US $\$ 400$ to US $\$ 800$ each (Ford et al. 2009). Another disadvantage of NGS is that age cannot be determined from DNA, and age-class information is very important to most wildlife studies. Photographs from remote cameras and track measurements taken from track pads can provide approximations of age class. Due to the lack of information gleaned from NGS on direction of movement and age of individuals, we recommend that our hair-sampling system always be used in conjunction with either track pads or remote cameras.

Radiotelemetry and global positioning system (GPS) methods have several advantages over NGS for monitoring wildlife crossing structures, but they also have limitations. Even with frequent locations obtained using current GPS collar technology (Waller and Servheen 2005), it would be difficult to determine exactly when and where an individual crossed the road. Intense sampling frequencies are required to determine fine-scale movements (Mills et al.2006) and battery life on most GPS transmitters precludes real-time monitoring, so crossing events could be easily missed. In the future, GPS collars could be extremely useful for examining fine-scale movement patterns and interactions with roads, but battery life must significantly improve before they can be used on their own. Until then, we also recommend the use of remote cameras and track pads with telemetry (VHF or GPS) when evaluating the effectiveness of wildlife crossing structures. 
Table 1. Comparative applicability of non-invasive genetic sampling (NGS) with other monitoring methods for addressing specific research objectives related to animal movement at wildlife crossing structures and population connectivity across roads. GPS $=$ global positioning system $. \mathrm{X}=$ best method, $\mathrm{x}=$ suitable method.

\begin{tabular}{|c|c|c|c|c|}
\hline \multirow[b]{2}{*}{ Research objectives } & \multicolumn{4}{|c|}{ Monitoring method } \\
\hline & Track pads & $\begin{array}{l}\text { Remote } \\
\text { cameras }\end{array}$ & $\begin{array}{l}\text { NGS } \\
\text { sampling }\end{array}$ & $\begin{array}{l}\text { Radio- } \\
\text { telemetry/ } \\
\text { GPS collars }\end{array}$ \\
\hline Species identification & $\mathrm{X}$ & $\mathrm{X}$ & $\mathrm{x}$ & $\mathrm{x}$ \\
\hline Direction of travel & $\mathrm{X}$ & $\mathrm{X}$ & & $\mathrm{X}$ \\
\hline Individual identification & & & $\mathrm{X}$ & $\mathrm{x}$ \\
\hline Sex determination & & & $\mathrm{X}$ & $\mathrm{x}$ \\
\hline Detection of juveniles using crossings with mother & $\mathrm{x}$ & $\mathrm{X}$ & $\mathrm{X}$ & $\mathrm{x}$ \\
\hline $\begin{array}{l}\text { Species-level spatial patterns (preference for crossing types by } \\
\text { species) }\end{array}$ & $X$ & $X$ & $\mathrm{x}$ & $\mathrm{x}$ \\
\hline $\begin{array}{l}\text { Species-level temporal patterns (annual and seasonal use by } \\
\text { species) }\end{array}$ & $\mathrm{X}$ & $X$ & $\mathrm{x}$ & $\mathrm{x}$ \\
\hline $\begin{array}{l}\text { Individual-level general spatial patterns (preference for } \\
\text { crossing types by individuals) }\end{array}$ & & & $\mathrm{X}$ & $X$ \\
\hline $\begin{array}{l}\text { Individual-level general temporal patterns (annual and seasonal } \\
\text { use by individuals) }\end{array}$ & & & $X$ & $X$ \\
\hline $\begin{array}{l}\text { Individual-level fine-scale spatial use (how are crossings } \\
\text { incorporated into home-range movements) }\end{array}$ & & & & $\mathrm{X}$ \\
\hline $\begin{array}{l}\text { Individual-level fine-scale temporal use (when do individuals } \\
\text { incorporate crossings into movements) }\end{array}$ & & & & $X$ \\
\hline $\begin{array}{l}\text { Population-level spatial patterns (context for crossing type } \\
\text { preferences) }\end{array}$ & & & $\mathrm{x}$ & $X$ \\
\hline $\begin{array}{l}\text { Population-level temporal patterns (context for annual and } \\
\text { seasonal use) }\end{array}$ & & & $\mathrm{x}$ & $\mathrm{X}$ \\
\hline Detection of long-distance disperser at crossings & & & $\mathrm{X}$ & \\
\hline $\begin{array}{l}\text { Estimate relationships and parentage of individuals using } \\
\text { crossings }\end{array}$ & & & $\mathrm{X}$ & $\mathrm{x}$ \\
\hline Estimate change in gene flow due to presence of crossings & & & $\mathrm{X}$ & $\mathrm{x}$ \\
\hline $\begin{array}{l}\text { Estimate change in population survival due to presence of } \\
\text { crossings }\end{array}$ & & & & $\mathrm{X}$ \\
\hline $\begin{array}{l}\text { Estimate change in population fecundity due to presence of } \\
\text { crossings }\end{array}$ & & & & $\mathrm{X}$ \\
\hline
\end{tabular}




\section{Applications for Management}

Our piloted non-invasive approach is part of a method with two sampling components, individuals using wildlife crossing structures and individuals within a focal population. The other sampling component requires collection of detailed information on the genetics of the focal population affected by transportation infrastructure. Methods of genetic sampling over large areas have been developed and refined over the last decade (Woods et al. 1999, Taberlet et al. 1996, Kendall et al. 2008) and are an integral part of the population-level analysis. The genetic data collected from the hairsampling methods to determine whether demographic and genetic connectivity has been restored across roads could have other applications for the conservation and management of wildlife populations.

Genetic data from the focal population could be used to monitor and estimate population size (Banks et al. 2003, Piggot and Taylor 2003, Pearse and Crandall 2004, Romain-Bondi et al. 2004), develop species occupancy models (MacKenzie et al. 2006, Pearce and Boyce 2006, Long et al. 2008), calculate migration rates (Manel et al. 2005, Dixon et al. 2006), and quantify the genetic population structure and connectivity gradients (Pearse and Crandall 2004, Proctor et al. 2005, Millions and Swanson 2007). This information could then be used to parameterize population viability and genetics models (Beissinger and McCullough 2002, Hanski and Gaggiotti 2004). Because each genetic sample is associated with a geographic coordinate in the study area, if repeated sampling of the same individual occurs, then crude home-range maps can be constructed for individuals with sufficient sample sizes (Taberlet et al. 2003).

Similar research questions for management can be addressed at different spatial scales and for different taxa. Wildlife tunnels and small culverts are often used by transportation agencies to mitigate road effects on small- and medium-sized mammals $(\mathrm{Ng}$ et al. 2004, Mata et al. 2005, Bond and Jones 2008). These tunnels and culverts are assumed to benefit target populations by reducing mortality and enhancing population connectivity. Many of these species have special habitat requirements and localized populations, and are strongly impacted by road-related mortality (Rondini and Doncaster 2002, Rytwinsky and Fahrig 2007, McGregor et al. 2008).
Obtaining empirical data demonstrating populationlevel benefits of crossing structures for these species may be less problematic and challenging than for the large, wide-ranging mammals in our study. Nonetheless, the application of the NGS technique for mammal species in ecosystems elsewhere could be complicated. Some data-collection problems we envision may consist of: (1) species occurring in high densities, thus a large number of hair samples collected and possibly cross-contamination of samples of multiple individuals, (2) the inability to collect hair samples on a daily basis or short time intervals and having samples damaged and DNA degrade, and (3) species that use canopy crossings for cross-road movement (Taylor and Goldingay 2009), thus funnelling passage of individuals through one confined space, increasing likelihood of coincident sampling of multiple individuals and DNA cross-contamination.

Designing a survey using NGS methods requires careful consideration of target species-specific behavior, single- vs. multiple-capture devices, and DNA quality and storage of samples. If there are abundant animals in the area (target or non-target) and hair-sampling success rate is high, hairsampling devices should be visited regularly to reduce the chance of cross-contamination and sampling multiple individuals. Multiple individuals or multiple species can result in failure to identify species or individuals. This can be avoided by analyzing single hairs, however, single hairs usually contain insufficient DNA for analysis. Single-hair amplifications can lead to allelic dropout or false alleles (Goosens et al. 1998). Error rates were reduced from $14 \%$ to $4.9 \%$ to $0.3 \%$ as the number of alpine marmot (Marmota marmota) hairs increased from one to three to ten hairs, respectively (Goosens et al. 1998).

Open hair-collection devices, including barbedwire devices such as the one we piloted or hair-corral methods (Kendall and McKelvey 2008) can capture hair from multiple individuals at a single site. But because there are many barbs available and movement is not concentrated, it is unlikely that two individuals will leave hair on the same barb. Furthermore, for some hair-sampling devices, once hair is snagged, it may be difficult to capture hair from additional animals visiting the device. For example, a barb full of hair will have insufficient room left on the barb to snag additional hair from other animals coming into contact with it. 
Mixed hair samples can result when movement of animals is concentrated or funnelled to one or few devices, such as cubbies (boxes or tubes used for hair capture; Long et al. 2008). For these situations, hair collection should occur at shorter intervals than at open hair-collection devices, if individual identification is needed. If for whatever reason the devices are likely to collect mixed samples, this can be minimized by reducing the total number of samples collected at each device. Using shorter intervals between visits or use of single-sampling hair traps is recommended (Bremner-Harrison et al. 2006, DePue and Ben-David 2007, Pauli et al. 2008). These devices terminate sampling after one animal visit. Even if our recommendations are followed to limit the number of mixed samples, inevitably some samples will be collected with DNA from more than one individual. Researchers should rest easy knowing that these samples can be easily detected and removed from further analyses by the detection of more than two alleles at a locus (Roon et al. 2005).

Storage of hair samples is important, such that DNA degradation is minimized (Roon et al. 2003). As a source of DNA, hair varies in quality and quantity depending on the particular species, the environment in which samples are collected, and whether the device plucks hair or collects shed hair (Long et al. 2008). The climate at hair-collection study sites influences the amount of useful DNA obtained. Moisture and ultraviolet light degrade DNA, with degradation increasing with the time of exposure. When sampling in forested habitats with dense canopies, although ultraviolet exposure is limited, moisture is the main concern. For best genotyping results, hair should not be left in the field in dry environments for more than 3-4 weeks and should be collected more frequently in wet or sunexposed environments (D. Paetkau, Wildlife Genetics International, personal communication).

Obtaining genetic samples from taxa that do not have hair or have short hair from which samples are not easily obtained can provide study design challenges. Most non-invasive methods have been focused on mammals (e.g., hair, feces, saliva) or birds (feathers). Sloughs in reptiles and shed skins in amphibians can be found in the field and used as sources of DNA, but are of limited value for most studies because they are not readily available. Eggshell membranes provided a reliable, noninvasive source of DNA for an endangered reptile
(Yun and Xiao-Bing 2008). Fortunately, many amphibian and reptile populations are locally abundant, thus allowing for application of broad range of research methods compared with elusive, wide-ranging large mammal species.

Hair is only one of several sample types that can be obtained non-invasively from mammals in the field. Feces and saliva samples are other means, the former being large enough usually to allow multiple attempts at DNA recovery (Schwartz and Monfort 2008). Fecal samples containing amplifiable DNA were collected while snowtracking Canada lynx and wolverine (McKelvey et al. 2006, Ulizio et al. 2006). However, collection of both hairs and feces provided $28 \%$ more track verifications than would have occurred using only one type of sample. Collecting multiple sample types for a target species not only provides more genetic material for analysis but reduces the sampling effort per sample.

Evaluations of the efficacy of wildlife crossing structures have typically focused on single species or groups of closely related species, thus leaving unanswered the question of whether they can effectively facilitate the flow of broader populationand community-level processes. Answering this question requires connectivity research that spans multiple crossing structures and species, rather than the observational studies that dominate the literature on the use of wildlife crossing structures (see Forman et al. 2003, Bissonette 2007, van der Ree et al. 2007). We encourage others to test the prototype system we have developed in Banff National Park for similar large-sized mammals, or similar noninvasive techniques with other taxa that should benefit from the investment in crossing structures.

Responses to this article can be read online at:

http://www.ecologyandsociety.org/voll5/iss1/art7/responses/

\section{Acknowledgments:}

We wish to acknowledge the following individuals and organizations for their valuable support, which has made this research possible. Jeremy Guth and the Woodcock Foundation believed in our research project from the start and, without their support, this would have never come to fruition. Ted Smith (Henry P. Kendall Foundation) and Tim Greyhavens 
(Wilburforce Foundation) were critically important partners who eventually helped gain support from the Western Transportation Institute (WTI) at Montana State University and Parks Canada Agency (PCA) in the Canadian Mountain Parks. Steve Albert and Rob Ament have been instrumental in keeping the research going, and Stephen Woodley, Jillian Roulet, Ian Syme, Ed Abbott, and Alan Dibb of Parks Canada have provided much-needed agency support. Kathy Rettie deserves special recognition for the complex, transboundary management of the project for PCA, which was difficult at best. Funding was obtained from an international public-private partnership formed by the three foundations, WTI, and PCA. Parks Canada funding came through a 3-year PCA Ecological Integrity Innovation and Leadership grant. WTI support came from the U.S. Department of Transportation University Transportation Center funding to WTI. We thank the Yellowstone to Yukon Conservation Initiative, especially Rob Buffler, for their support and for acting as our fiscal agent in Canada. We thank the Calgary Foundation, the Dunlop Family Fund, and the Mountain Equipment Cooperative (MEC) for funding this important work and transfer of technology through education and outreach activities. Dave Poulton and Gregoire Belland from the Canadian Parks and Wilderness Society assisted in managing funding from MEC.

\section{LITERATURE CITED}

Aars, J., and R. A. Ims. 1999. The effect of habitat corridor on rates of transfer and interbreeding between vole demes. Ecology 80:1648-1655.

Apps, C. D., B. N. McLellan, J. G. Woods, and M. F. Proctor. 2004. Estimating grizzly bear distribution and abundance relative to habitat and human influence. Journal of Wildlife Management 68: $138-152$.

Balkenhol, N., and L. P. Waits. 2009. Molecular road ecology: exploring the potential of genetics for investigating transportation impacts on wildlife. Molecular Ecology 18:4151-4164.

Banff-Bow Valley Study. 1996. Banff-Bow Valley: at the crossroads. Summary report for the BanffBow Valley Task Force. Canadian Heritage, Ottawa, Ontario, Canada.
Banks, S. C., S. D. Hoyle, A. Horsup, P. Sunnucks, and A. C. Taylor. 2003. Demographic monitoring of an entire species (the northern hairy-nosed wombat, Lasiorhinus krefftii) by genetic analysis of non-invasively collected material. Animal Conservation 6:101-107.

Beier, P., and R. Noss. 1998. Do habitat corridors provide connectivity? Conservation Biology 12:1241-1252.

Beissinger, S. R., and D. R. McCullough. 2002. Population viability analysis. University of Chicago Press, Chicago, Illinois, USA.

Bennett, A. F. 1999. Linkages in the landscape: the role of corridors and connectivity in wildlife conservation. IUCN, Gland, Switzerland and Cambridge, UK.

Bider, J. R. 1968. Animal activity in uncontrolled terrestrial communities as determined by a sand transect technique. Ecological Monographs 38:274-291.

Bissonette, J. A. 2007. Evaluation of the use and effectiveness of wildlife crossings. National Cooperative Highway Research Program (NCHRP) 25-27 final report. Transportation Research Board, Washington, D.C., USA.

Bond, A. R., and D. N. Jones. 2008. Temporal trends in use of fauna-friendly underpasses and overpasses. Wildlife Research 35:103-112.

Boulanger, J., G. C. White, B. N. McLellan, J. Woods, M. Proctor, and S. Himmer. 2002. A metaanalysis of grizzly bear DNA mark-recapture projects in British Columbia. Ursus 13:137-152.

Bremner-Harrison, S., W. R. Harrison, B. L. Cypher, J. D. Murdoch, J. Maldonado, and S. K. Darden. 2006. Development of a single-sampling non-invasive hair snare. Wildlife Society Bulletin 34:456-461.

Carroll, C. 2006. Linking connectivity to viability: insights from spatially explicit population models of large carnivores. Pages 369-389 in K. Crooks and M. Sanjayan, editors, Connectivity conservation. Cambridge University Press, New York, New York, USA.

Chruszcz, B., A. P. Clevenger, K. Gunson, and 
M. Gibeau. 2003. Relationships among grizzly bears, highways, and habitat in the Banff-Bow Valley, Alberta, Canada. Canadian Journal of Zoology 81:1378-1391.

Clevenger, A. P., B. Chruszcz, and K. Gunson. 2003. Spatial patterns and factors influencing small vertebrate fauna road-kill aggregations. Biological Conservation 109:15-26.

Clevenger, A. P., B. Chruszcz, K. Gunson, and J. Wierzchowski. 2002. Roads and wildlife in the Canadian Rocky Mountain parks-movements, mortality and mitigation. Final Report (October 2002). Report prepared for Parks Canada, Banff, Alberta, Canada.

Clevenger, A. P., A. T. Ford, and M. A. Sawaya. 2009. Banff wildlife crossings project: integrating science and education in restoring population connectivity across transportation corridors. Final report to Parks Canada Agency, Radium Hot Springs, British Columbia, Canada.

Clevenger, A. P., and N. Waltho. 2000. Factors influencing the effectiveness of wildlife underpasses in Banff National Park, Alberta, Canada. Conservation Biology 14:47-56.

Clevenger, A. P., and N. Waltho. 2005. Performance indices to identify attributes of highway crossing structures facilitating movement of large mammals. Biological Conservation 121:453-464.

Coffman, C. J., J. D. Nichols, and K. H. Pollack. 2001. Population dynamics of Microtus pennsylvanicus in corridor-linked patches. Oikos 93:3-21.

Corlatti, L., K. Hacklander, and F. Frey-Roos. 2009. Ability of wildlife overpasses to provide connectivity and prevent genetic isolation. Conservation Biology 23:548-556.

Creel, S., G. Spong, J. L. Sands, J. J. Rotella, J. Zeigle, L. Joe, K. M. Murphy, and D.Smith. 2003. Population size estimation in Yellowstone wolves with error-prone non-invasive microsatellite genotypes. Molecular Ecology 12:2003-2009.

Crooks, K. R., and M. Sanjayan, editors. 2006. Connectivity conservation. Cambridge University Press, Cambridge, UK.
Cushman, S., K. S. McKelvey, J. Hayden, and M. K. Schwartz. 2006. Gene flow in complex landscapes: testing multiple hypotheses with causal modeling. American Naturalist 168:486-499.

Damschen, E. I., N. M. Haddad, J. L. Orrock, J. J. Tewksbury and D. J. Levey. 2006. Corridors increase plant species richness at large scales. Science 313:1284-1286.

Davenport, J., and J. L. Davenport, editors. 2006. The ecology of transportation: managing mobility for the environment. Springer, London, UK.

DePue, J. E. and M. Ben-David. 2007. Hair sampling techniques for river otters. Journal of Wildlife Management 71:671-674.

Dixon, J. D., M. K. Oli, M. C. Wooten, T. H. Eason, J. W. McCown, and D. Paetkau. 2006. Effectiveness of a regional corridor in connecting two Florida black bear populations. Conservation Biology 20:155-162.

Dodd, C. K., W. J. Barichivich, and L. L. Smith. 2004. Effectiveness of a barrier wall and culverts in reducing wildlife mortality on a heavily traveled highway in Florida. Biological Conservation 118:619-631.

Dodd, N., J. Gagnon, S. Boe, and R. Schweinsburg. 2007a. Assessment of elk highway permeability by using global positioning system telemetry. Journal of Wildlife Management 71:1107-1117.

Dodd, N., J. Gagnon, A. L. Manzo, and R. E. Schweinsburg. 2007b. Video surveillance to assess highway underpass use by elk in Arizona. Journal of Wildlife Management 71:637-645.

Durnin, M. E., P. J. Palsboll, O. A. Ryder, and D. R. McCullough. 2007. A reliable genetic technique for sex determination of giant panda (Ailuropoda melanoleuca) from non-invasively collected hair samples. Conservation Genetics 8:715-720.

Epps, C. W., P. J. Palsbøll, J. D. Weyhausen, G. K. Roderick, R. R. Ramey, and D. R. McCullough. 2005. Highways block gene flow and cause a rapid decline in genetic diversity of desert bighorn sheep. Ecology Letters 8:1029-1038. 
Evink, G., 2002. Interaction between roadways and wildlife ecology: a synthesis of highway practice. National Cooperative Highway Research Program Synthesis 305. Transportation Research Board, Washington, D.C., USA.

Flagstad, O., E. Hedmark, A. Landa, H. Broseth, J. Persson, R. Andersen, P. Segerstrom, and $\mathbf{H}$. Ellegren. 2004. Colonization history and noninvasive monitoring of a reestrablished wolverine population. Conservation Biology 18:676-688.

Foran, D.S., K. C. Crooks, and S. C. Minta. 1997. DNA-based analysis of hair to identify species and individuals for population research and monitoring. Wildlife Society Bulletin 25:840-847.

Ford,A. F., A. P. Clevenger, and A. Bennett. 2009. Comparison of non-invasive methods for monitoring wildlife crossing structures on highways. Journal of Wildlife Management 73:1213-1222.

Forman, R. T. T. and L. E.Alexander. 1998. Roads and their major ecological effects. Annual Review of Ecology and Systematics 29:207-231.

Forman, R. T. T., D. Sperling, J. Bissonette, A. Clevenger, C. Cutshall, V. Dale, L. Fahrig, R. France, C. Goldman, K. Heanue, J. Jones, F. Swanson, T. Turrentine, and T. Winter. 2003. Road ecology: science and solutions. Island Press, Washington, D.C., USA.

Foster, M. L., and S. R. Humphrey. 1995. Use of highway underpasses by Florida panthers and other wildlife. Wildlife Society Bulletin 23:95-100.

Frantz, A. C., M. Schaul, L. C. Pope, F. Fack, L. Schley, C. P. Muller, and T. J. Roper. 2004. Estimating population size by genotyping remotely plucked hair: the Eurasian badger. Journal of Applied Ecology 41:985-995.

Gagnon, J. W., T. C. Theimer, N. L. Dodd, A. Manzo, and R. Schweinsburg. 2007. Effects of traffic use on elk use of wildlife underpasses in Arizona. Journal of Wildlife Management 71:23242328.

Gibeau, M. L. 2000. A conservation biology approach to management of grizzly bears in Banff National Park, Alberta. Dissertation, University of
Calgary, Calgary, Alberta, Canada.

Gibeau, M. L, A. P. Clevenger, S. Herrero, and J. Wierzchowski. 2002. Grizzly bear response to human development and activities in the Bow River watershed, Alberta. Biological Conservation 103:227-236.

Goosem, M., Y. Izumi, and S. Turton. 2001. Efforts to restore habitat connectivity for an upland tropical rainforest fauna: a trial of underpasses below roads. Ecological Management and Restoration 2:196-202.

Goossens, B., L. P. Waits, and P. Taberlet. 1998. Plucked hair samples as a source of DNA: reliability of dinucleotide microsatellite genotyping. Molecular Ecology 7: 1237-1241.

Grilo, C., J. A. Bissonette, and M. Santos-Reis. 2008. Response of carnivores to existing highway culverts and underpasses: implications for road planning and mitigation. Biodiversity and Conservation 17:1685-1699.

Hamer, D., and S. Herrero. 1987. Grizzly bear food and habitat in the front ranges of Banff National Park, Alberta. International Conference on Bear Research and Management 7:199-213.

Hanksi, I., and O. E. Gaggiotti. 2004. Ecology, genetics, and evolution of metapopulations. Elsevier Academic Press, New York, New York, USA.

Hebblewhite, M., M. Percy, and R. Serrouya. 2003. Black bear survival and demography in the Bow Valley of Banff National Park, Alberta. Biological Conservation 112:415-425.

Heller, N. E., and E. S. Zavaleta. 2009. Biodiversity management in the face of climate change: a review of 22 years of recommendations. Biological Conservation 142:14-32.

Hobson, K. A., 2005. Using stable isotopes to trace long-distance dispersal in brids and other taxa. Diversity and Distributions 11:157-164.

Huck, M., A. C. Frantz, D. A. Dawson, T. Burke, and T. J. Roper. 2008. Low genetic variability, female-biased dispersal and high movement rates in an urban population of Eurasian badgers Meles meles. Journal of Animal Ecology 77:905-915. 
Huijser, M. P., P. McGowen, J. Fuller, A. Hardy, A. Kociolek, A. P. Clevenger, D. Smith and R. Ament. 2007. Wildlife-vehicle collision reduction study. Report to congress. U.S. Department of Transportation, Federal Highway Administration, Washington D.C., USA.

Johnson, W. E., and S. J. O'Brien. 1997. Phylogenetic reconstruction of the felidae using $16 \mathrm{~S}$ rRNA and NADH-5 mitochondrial genes. Journal of Molecular Evolution 44:S98-116.

Kadoya, T. 2009. Assessing functional connectivity using empirical data. Population Ecology 51:5-15.

Kalinowski, S. T., M.A. Sawaya, and M. L. Taper. 2006. Individual identification and distribution of genotypic differences between individuals. Journal of Wildlife Management 70:1148-1150.

Kendall, K. C, and K. S. McKelvey. 2008. Hair collection. Pages 141-182 in R. Long, P. MacKay, W. J. Zielinski and J. C. Ray, editors. Non-invasive survey methods for carnivores. Island Press, Washington, D.C., USA.

Kendall, K. C., J. B. Stetz, J. Boulanger, A. C. Macleod, D. Paetkau, and G. C. White. 2009. Demography and genetic structure of a recovering grizzly bear population. Journal of Wildlife Management 73:3-17.

Kendall, K. C., J. B. Stetz, D. A. Roon, L. P. Waits, J. B. Boulanger, and D. Paetkau. 2008. Grizzly bear density in Glacier National Park, Montana. Journal of Wildlife Management 72:1693-1705.

Keyghobadi, N., J. Roland, and C. Strobeck. 2005. Genetic differentiation and gene flow among populations of the alpine butterfly, Parnassius smintheus, vary with landscape connectivity. Molecular Ecology 14:1897-1909.

Kindlmann, P., and F. Burel. 2008. Connectivity measures: a review. Landscape Ecology 23:879890.

Kleist, A. M., R. A. Lancia, and P. D. Doerr. 2007. Using video surveillance to estimate wildlife use of a highway underpass. Journal of Wildlife Management 71:2792-2800.

Lapointe, S. D., R. W. Kays, and J. C. Ray. 2003. Animals crossing the northway: are existing culverts useful? Adirondack Journal of Environmental Studies, Spring/Summer:11-17.

Linnell, J. D. C., R. Andersen, T.Kvam, H. Andren, O. Liberg, J. Odden, and P. F. Moa. 2001. Home range size and choice of management strategy for lynx in Scandinavia. Environmental Management 27:869-879.

Long, R. A., P. MacKay, W. J. Zielinski, and J. C. Ray, editors. 2008. Noninvasive survey methods for carnivores. Island Press, Washington D.C., USA.

MacKenzie, D. I., J. D. Nichols, J. A. Royale, K. H. Pollock, L. L. Bailey and J. E. Hines. 2006. Occupancy estimation and modeling: inferring patterns and dynamics of species occurrence. Academic Press, New York, New York, USA.

Manel. S., O. E. Gaggiotti, and R. S. Waples. 2005. Assignment methods: matching biological questions with appropriate techniques. Trends in Ecology and Evolution 20:136-142.

Mansergh, I. M. and D. J. Scotts. 1989. Habitat continuity and social organization of the mountain pygmy-possum restored by tunnel. Journal of Wildlife Management 53:701-707.

Marsh, D., R. Page, T. Hanlon, R. Corritone, E. Little, D. Seifert, and P. Cabe. 2008. Effects of roads on patterns of genetic differentiation in redbacked salamanders, Plethodon cinereus. Conservation Genetics 9:603-613.

Mata, C., I. Hervás, J. Herranz, F. Suárez, and J. E. Malo. 2005. Complementary use by vertebrates of crossing structures along a fenced Spanish motorway. Biological Conservation 124:397-405.

McGregor, R. L., D. J. Bender, and L. Fahrig. 2008. Do small mammals avoid roads because of traffic? Journal of Applied Ecology 45:117-123.

McGuire, T. M., and J. F. Morrall. 2000. Strategic highway improvements to minimize environmental impacts within the Canadian Rocky Mountain national parks. Canadian Journal of Civil Engineering 27:523-532.

McKelvey, K. S., J. von Kienast, K. B. Aubry, G. M. Koehler, B. Maletzke, J. Squires, E. 
Lindquist, S. Loch, and M. K. Schwartz. 2006. DNA analysis of hair and scat collected alolng snow tracks to document presence of Canada lynx. Wildlife Society Bulletin 34:451-455.

McRae, B. H., P. Beier, L. E. DeWald, L. Y. Huynh, and P. Keim. 2005. Habitat barriers limit gene flow and illuminate historical events in a wideranging carnivore, the American puma. Molecular Ecology 14:1965-1977.

Millions, D. G., and B. J. Swanson. 2007. Impact of natural and artificial barriers to dispersal on the population structure of bobcats. Journal of Wildlife Management 71:96-102.

Mills, K. J., B. R. Patterson, and D. L. Murray. 2006. Effects of variable samplilng frequencies on GPS transmitter efficiency and estimated wolf home range size and movement distance. Wildlife Society Bulletin 34:1463-1469.

Mowat, G., and D. Paetkau. 2002. Estimating marten Martes americana population size using hair capture and genetic tagging. Wildlife Biology 8:201-209.

Mowat, G., and C. Strobeck. 2000. Estimating population size of grizzly bears using hair capture, DNA profiling, and mark-recapture analysis. Journal of Wildlife Management 63:911-920.

Mumme, R. L., S. J. Schoech, G. E. Woolfenden, and J. W. Fitzpatrick. 2000. Life and death in the fast lane: demographic consequences of road mortality in the Florida scrub-jay. Conservation Biology 14:501-512.

Nathan, R., G. Perry, J. T. Cronin, A. E. Strand, and M. L. Cain. 2003. Methods for estimating longdistance dispersal. Oikos 103:261-273.

Nathan, R., W. M. Getz, E. Revilla, M. Holyoak, R. Kadmon, D. Saltz, and P. E. Smouse. 2008. A movement ecology paradigm for unifying organismal movement research. Procedings of the National Academy of Sciences of the USA 105:19052-19059.

National Research Council. 2005. Assessing and managing the ecological impacts of paved roads. The National Academies Press, Washington, D.C., USA.
Ng, S. J., J. W. Dole, R. M. Sauvajot, S. P. Riley, and T. J. Valone. 2004. Use of highway undercrossings by wildlife in southern California. Biological Conservation 115:499-507.

Paetkau, D. 2003. An empirical exploration of data quality in DNA-based population inventories. Molecular Ecology 12:1375-1387.

Pauli, J. N., M. B. Hamilton, E. B. Crain, and S. W. Buskirk. 2008. A single-sampling hair trap for mesocarnivores. Journal of Wildlife Management 72:1650-1652.

Pearce, J. L, and M. S. Boyce. 2006. Modelling distribution and abundance with presence-only data. Journal of Applied Ecology 43:405-412.

Pearse, D. E., and K. A. Crandall. 2004. Beyond $\mathrm{F}_{\mathrm{st}}$ : analysis of population genetic data for conservation. Conservation Genetics 5:585-602.

Piggot, M. P., and A. C. Taylor. 2003. Remote collection of animal DNA and its application in conservation management and understanding the population biology of rare and cryptic species. Wildlife Research 30:1-13.

Powell, R. A. 2000. Animal home ranges and territories and home range estimators. Pages 65-110 in L. Boitani and T. K. Fuller, editors, Research techniques in animal ecology: controversies and consequences. Columbia University Press, New York, New York, USA.

Proctor, M. F., B. N. McLellan, C. Strobeck and R. M. R. Barclay. 2005. Genetic analysis reveals demographic fragmentation of grizzly bears yielding vulnerably small populations. Proceedings of the Royal Society of London, Series B 272:24092416.

Reed, J. Z, D. J. Tollit, P. M. Thompson, and W. Amos. 1997. Molecular scatology: the use of molecular genetic analysis to assign species, sex and individual identity to seal faeces. Molecular Ecology 6:225-234.

Rettie, K., A. P. Clevenger, and A. T. Ford. 2009. Innovative approaches for managing conservation and use challenges in the national parks: an example from Canada. Pages 396-415 in T. Jamal and M. Robinson, editors. Handbook of Tourism Studies. 
Sage Publications Inc., Thousand Oaks, California, USA.

Riley, S. P. D., J. P. Pollinger, R. M. Sauvajot, E. C. York, C. Bromley, T. K. Fuller, and R. K. Wayne. 2006. A southern California freeway is a physical and social barrier to gene flow in carnivores. Molecular Ecology 15:1733-1741.

Rodríguez, A., G. Crema, and M. Delibes. 1997. Factors affecting crossing of red foxes and wildcats through non-wildlife passages across a high-speed railway. Ecography 20:287-294.

Rogers, L. L. 1987. Effects of food supply and kinship on social behavior, movements, and population growth of black bears in northeastern Minnesota. Wildlife Monographs 97:1-72.

Romain-Bondi, K. A., R. B. Wielgus, L. Waits, W. F. Kasworm, M. Austin, and W. Wakkinen. 2004. Density and population size estimates for North Cascade grizzly bears using DNA hairsampling techniques. Biological Conservation 117:417-428.

Rondinini, C., and C. P. Doncaster. 2002. Roads as barriers to movement for hedgehogs. Functional Ecology 16:504-509.

Roon, D. A., M. E. Thomas, K. C. Kendall, and L. P. Waits. 2005. Evaluating mixed samples as a source of error in non-invasive genetic studies using microsatellites. Molecular Ecology 14:195-201.

Roon, D. A., L. P. Waits, and K. C. Kendall. 2003. A qualitative evaluation of two methods for preserving hair samples. Molecular Ecology Notes 3:163-166.

Rytwinsky, T., and L. Fahrig. 2007. Effect of road density on abundance of white-footed mice. Landscape Ecology 22:1501-1512.

Schwartz, M. K., L. S. Mills, Y. Ortega, L. F. Ruggiero, and F. W. Allendorf. 2003. Landscape location affects genetic variation of Canada lynx (Lynx canadensis). Molecular Ecology 12:18071816.

Schwartz, M. K., and S. L. Monfort. 2008. Genetic and endocrine tools for carnivore surveys. Pages 238-262 in R. Long, P. Mackay, W. Zielinski, and J. Ray, editors. Non-invasive survey methods for carnivores. Island Press, Washington, D.C., USA.

Sloane, M. A., P. Sunnucks, D. Alpers, L. B. Beheregaray, and A. C. Taylor. 2000. Highly reliable genetic identification of individuals north hairy-nosed wombats from single remotely collected hairs: a feasible censusing method. Molecular Ecology 9:1233-1240.

Spellerberg, I. F. 2002. Ecological effects of roads. Science Publisher Inc., Plymouth, UK.

Stenhouse, G., J. Boulanger, J. Lee, K. Graham, J. Duval, and J. Cranston. 2005. Grizzly bear associations along the eastern slopes of Alberta. Ursus 16:31-40.

Strasburg, J. L. 2006. Roads and genetic connectivity. Nature 440:875-876.

Swanson, F. J., T. K. Kratz, N. Caine, and R. G. Woodmansee. 1988. Landform effects on ecosystem patterns and processes. Bioscience 38:92-98.

Taberlet, P., J.-J. Camarra, S. Griffin, E. Uhres, O. Hanotte, L. P. Waits, C. Dubois-Paganon, T. Burke, and J. Bouvet. 2003. Noninvasive genetic tracking of the endangered Pyrenean brown bear population. Molecular Ecology 6:869-876.

Taberlet, P., S. Griffin, B. Goossens, S. Questiau, V. Manceau, N. Escaravage, L. P. Waits, and J. Bouvet. 1996. Reliable genotyping of samples with very low DNA quantities using PCR. Nucleic Acids Research. 24: 3189-3194.

Taylor, B. D., and R. L. Goldingay. 2009. Wildlife tunnel enhances population viability. Ecology and Society 14(2): 13. [online] URL: http://www.ecolog yandsociety.org/vol14/iss2/art13/.

Transportation Research Board. 1997. Toward a sustainable future: addressing the long-term effects of motor vehicle transportation on climate and ecology. Special report 251, National Academy Press, Washington, D.C., USA.

Ulizio, T. J., J. R. Squires, D. H. Pletscher, M. K. Schwartz, J. Claar, and L. F. Ruggiero. 2006. The efficacy of obtaining genetic based identifications of putative wolverine snow tracks. Wildlife Society Bulletin 34:1326-1332. 
van der Ree, R., D. Heinze, M. McCarthy, and I. Mansergh. 2009. Wildlife tunnel enhances population viability. Ecology and Society 14(2): 7. [online] URL: http://www.ecologyandsociety.org/voll4/ iss $2 / \operatorname{art} 7 /$.

van der Ree, R., E. van der Grift, C. Mata, and F. Suarez. 2007. Overcoming the barrier effect of roads-how effective are mitigation strategies? An international review of the use and effectiveness of underpasses and overpasses designed to increase the permeability of roads for wildlife. Pages 423-431 in C. L. Irwin, D. Nelson, and K. P. McDermott, editors. Proceedings of the 2007 International Conference on Ecology and Transportation. Center for Transportation and Environment, North Carolina State University, Raleigh, North Carolina, USA.

van Vuurde, M. R., and E. A. van der Grift. 2005. The effects of landscape attributes on the use of small wildlife underpasses by weasel and stoat. Lutra 48:91-108.

Vos, C. C., P. Berry, P. Opdam, H. Baveco, B. Nijhof, J. O'Hanley, C. Bell, and H. Kuipers. 2008. Adapting landscapes to climate change: examples of climate-proof ecosystem networks and priority adaptation zones. Journal of Applied Ecology 45:1722-1731.

Vos, C. C., and J. P. Chardon. 1998. Effects of habitat fragmentation and road density on the distribution pattern of the moor frog Rana arvalis. Journal of Applied Ecology 35:44-56.

Waits, L. P., and P. Leberg. 2000. Biases associated with population estimation using molecular tagging. Animal Conservation 3:191199.

Waller, J. S. and C. Servheen. 2005. Effects of transportation infrastructure on grizzly bears in northwestern Montana. Journal of Wildlife Management 69:985-1000.

Weaver, J. L., P. Paquet, and L. F. Ruggiero. 1996. Resilience and conservation of large carnivores in the Rocky Mountains. Conservation Biology 10:964-976.

Webster, M. S., P. P. Marra, S. M. Haig, S. Bensch, and R. T. Holmes. 2002. Links between worlds: unraveling migratory connectivity. Trends in Ecology and Evolution 17:76-83.

Woods J. G., D. Paetkau, D. Lewis, B. L. McLellan, M. Proctor, and C. Strobeck. 1999. Genetic tagging of free-ranging black and brown bears. Wildlife Society Bulletin 27:616-627.

Yanes, M., J. M. Velasco, and F. Suárez. 1995. Permeability of roads and railways to vertebrates: the importance of culverts. Biological Conservation 71:217-222.

Yun, H., and W. Xiao-Bing. 2008. Eggshell membranes as a non-invasive sampling for molecular studies of Chinese alligators. African Journal of Biotechnology 7:3022-3025. 